\title{
психологія
}

\section{DOI: 10.31548/hspedagog2021.03.026}

УДК $159.9: 616.8$

ПСИХОТЕРАПЕВТИЧНІ МЕТОДИ ЛІКУВАННЯ ТРИВОЖНО-ФОБІЧНИХ РОЗЛАДІВ: КОРОТКИЙ ОГЛЯД

ДАНИЛОВА Т. В. , кандидат фрілософських наук, доцент, старший науковий співробітник лабораторії психології масової комунікації та медіаосвіти

Інститут соціальної та політичної психології НАПН України

ORCID ID 0000-0002-0297-9473

Email: danilova tv@ukr.net

САЛАТА Г. В. , доктор історичних наук, доцент,

доцент кафедри інформаційних технологій

Київський національний університет культури і мистецтв

ORCID ID 0000-0002-2673-8463

E-mail: salaty@bigmir.net

СЕМЕНОВ Ю. О., магістр 2 р. н., спеціальність «Психологія»

Національний університет біоресурсів і природокористування України ORCID ID 0000-0002-4464-5383

\section{Email: ysem@ukr.net}

\begin{abstract}
Анотація. Сьогодні все гостріше стає проблема діагностики, інтерпретації та вибору адекватних методів лікування тривожно-фробічних розладів з урахуванням багатовимірності людини. Отримані дані щодо психофармакотерапії демонструють їі помірну ефрективність при тривожнофообічних розладах. Значно ефрективніше спрацьовує поєднання психофрармакотерапії та психотерапії, яка часто відіграє провідну роль у процесі лікування. Метою статmі $\epsilon$ частковий аналіз психотерапевтичних методів лікування тривожно-фобічних розладів, таких як експозиційна терапія, когнітивнобіхевіоральна терапія, групова терапія та групи самодопомоги, гіпнотерапія, майндфулнес, медитація, глибоке дихання, метод прогресивної м'язової релаксації. Існують плюси $і$ мінуси як для психофрармакологічного, так $i$ для психотерапевтичного лікування. Отже, найефективніші стратегії лікування мають обиратися після глибокого багатопланового дослідження пацієнта $i$ здійснюватися поліпрофільною командою фрахівців.
\end{abstract}

Ключові слова: тривожно-фробічні розлади; експозиційна терапія; когнітивно-біхевіоральна терапія; групова терапія та групи самодопомоги; гіпнотерапія; майндфулнес; медитація; глибоке дихання; метод прогресивної м'язової релаксації.

Актуальність. Одними 3 найпоширеніших тривожних розладів, які негативно впливають як на окрему людину, так і на суспільство в цілому, спричиняючи значне погіршення психічного і фрізичного стану, зниження продуктивності праці, інвалідність, є тривожно-фобічні розлади (ТФР). Вони можуть бути предиктором посилення суїцидальної схильності, фрактором ризику подальшого розвитку панічних і депресивних розладів, обсесивнокомпульсивного розладу, різних видів залежності тощо. Тривожно-фобічні розлади - це група розладів, в клінічній картині яких переважає тривога, страх певних ситуацій або об'єктів (зовнішніх по відношенню до 
суб'єкта), які не становлять реальної небезпеки. У результаті людина намагається уникати таких ситуацій, або, опинившись у них, змушена долати почуття страху. Безперечно, кожна людина відчуває страх, адже страх - це цілком природна людська емоція, яка допомагає підготуватися до небезпеки і адекватно відреагувати на неї. Проте, у деяких людей страхи є більш вираженими і проявляються у вигляді фобії. Фобії надзвичайно ускладнюють життя, a у важких випадках вони можуть вплинути на здоров'я людини, її самопочуття та весь спосіб існування. Хоча дослідженню тривожно-фоббічних розладів приділяють сьогодні велику увагу, з ускладненням сучасного світу виникає все більше нових фобій, які інколи можуть залишатися непоміченими або не так інтерпретованими. Таким чином, все гостріше стає проблема діагностики, інтерпретації та вибору адекватних методів лікування ТФР з урахуванням багатовимірності людини.

Аналіз останніх досліджень та публікацій. Чимало дослідників приділяють значну увагу причинам, наслідкам та методам лікування тривожно-фробічних розладів. У ґрунтовній роботі «Phobias: The Psychology of Irrational Fear» представлено всебічний, науково обґрунтований аналіз фобій, розкрито історичний і культурний аспекти фобій, феноменологію, класифрікацію, діагностику, етіологічні моделі та методи лікування [11]. Техніки боротьби з ірраціональними страхами досліджено X. Саул в роботі «Phobias: Fighting the Fear» [15]. Р.Гарсія підкреслює, що, хоча страх $\epsilon$ адаптивним компонентом реакції на потенційно загрозливі стимули, занадто великий ірраціональний страх стає підґрунтям хронічних психічних розладів, включаючи посттравматичний стресовий розлад та фобої. Отже, розуміння нейробіологічної основи страху має вирішальне значення для з'ясування механізмів, що покращують лікування патологій, пов'язаних зі страхом [6].

Метою статті $\epsilon$ частковий аналіз психотерапевтичних методів лікування тривожно-фобічних розладів.

Методи. Був проведений широкий літературний огляд відповідних статей за період 20002020 рр. із використанням баз даних Google Scholar, PubMed та Scopus із такими ключовими словами: «тривожно-фробічний розлад, агорафобія, соціальний тривожний розлад, специфічна фобія, когнітивнобіхевіоральна терапія, експозиційна терапія, майндфулнес, медитація». Поряд 3 цим автори використовували інтегративний антропологічний підхід та інтерпретаційну парадигму дослідження.

Результати. Розлади, пов'язані зі страхом і тривогою, мають френоменологічну подібність. Це можуть бути такі фрізіологічні показники як збільшення частоти серцевих скорочень, надмірне потовиділення та гіпервентиляція або поведінкові дії, такі як втеча та уникнення. МКХ-11 також наголошує на широкому діапазоні можливих емоційних реакцій, які можуть включати сором, злість або огиду. Нова класифрікація не розрізняє фробічні тривожні розлади та інші тривожні розлади. Агорафобію розглядають як окрему діагностичну одиницю, а специфікатор панічної атаки застосовується за умов, коли панічні атаки $\epsilon$ реакцією на вплив агорафобних ситуацій [10]. Відповідно до МKX-11, можна виділити такі категорії фробій як агорафобія, соціальний тривожний розлад, специфічна фоббія [7].

Фобії піддаються лікуванню, і люди, які живуть 3 фобічним розладом, майже завжди усвідомлюють свій розлад, що $\epsilon$ суттєвою допомогою при діагностиці. Більшість фоббій можна вилікувати за допомогою адекватних стратегій, які мають бути адаптованими до 
конкретного індивіда, оскільки не існує єдиного лікування, яке підходить для кожної людини з фобією.

Деякі

дослідження

підтверджують ефрективність як психофрармакотерапії (препарати груп селективних інгібіторів зворотного захоплення серотоніну,

бензодіазепінових та небензодіазепінових анксиолітиків, атипових нейролептиків тощо), так і психотерапії [5]. Отримані дані щодо багатьох препаратів показують помірну ефективність при тривожнофобічних розладах. Значно ефективніше спрацьовує поєднання психофрармакотерпіi та психотерапії, яка часто відіграє провідну роль в процесі лікування. Розмовна терапія, що застосовується при консультуванні, $€$ корисною для лікування складних фобій.

Експозиційна терапія - це тип поведінкової терапії. При такому лікуванні терапевт, як правило, починає 3 тренувань в техніках релаксації, які можуть заспокоїти людину, що перебуває в стані сильного стресу. Іншим підходом до експозиційної терапії $€$ систематична десенсибілізація. Це процес поступового «входження» в ситуації, що провокують страх: від найменш страшних до найстрашніших. Після того, як людина з тривожно-фобічним розладом навчиться заспокоювати себе під час стресу, вона та ії терапевт зможуть побудувати ієрархію переживань, пов'язаних 3 фобіями. Експозиційна терапія - це спосіб поступово наблизити людину до того, чого вона боїться. Зазвичай це починається у її уяві, потім, наприклад, у різних мульторільмах, малюнках чи фотографріях. При зіткненні з кожним із рівнів страху терапевт допомагає клієнтам, проводячи їх через ці щаблі, використовуючи навички розслаблення, щоб заспокоїти тривогу. При послабленні рівня тривоги, пов'язаної 3 одним видом репрезентацій, клієнт разом 3 терапевтом переходять до вищого рівня. Мета експозиції полягає в систематичній десенсибілізації клієнта до конкретної фробії, аби клієнт позбувся симптомів, які заважають прожити своє життя на повну [9].

Когнітивно-біхевіоральна

терапія $€$ одним із найчастіше використовуваних підходів, оскільки вона допомагає людям переглянути інтерпретацію ситуацій, дозволяючи їм знаходити шляхи більш конструктивної боротьби зі своїми тривогами [1]. Когнітивно-біхевіоральні терапевти також заохочуватимуть клієнтів дослідити деякі складні причини, що лежать в основі їхньої тривоги, щоб допомогти їм краще зрозуміти це і побачити ситуацію в реалістичному аспекті, оскільки люди з тривожнофобічними розладами «формують» навколо фобії моделі мислення, які не засновані на дійсності. Когнітивнобіхевіоральна терапія допомагає людям виявити свої когнітивні спотворення. У рамках даного підходу проясняється механізм переходу нормальної тривоги, яка носить лінійний характер, у тривожний розлад, при якому тривога має циклічний характер. При тривожних розладах тривожна реакція не зникає. Когнітивні інтерпретації людини можуть стати неадекватними, що призводить до виникнення підтримуючого циклу. Тобто, після того як небезпечну ситуацію завершено, тривога залишається. Розвивається патерн уникання, що не надає можливості перевірити правильність когнітивних інтерпретацій. Когнітивне спотворення закріплюється і сприймається як одна-єдина реальність, що, в свою чергу, призводить до неадекватних дій, спрямованих на зменшення загрози. Це класична ситуація, яка підтверджує думку, що ми маємо справу не 3 фактами, а лише з інтерпретаціями.

Пацієнтам із сильним страхом перед фоббічним епізодом когнітивнобіхевіоральна терапія допомагає 
«пригадати», що у них фробія, що цей епізод має кінець; допомагає «побачити» думки, які посилюють страх і спричиняють неадекватну поведінку; сприяє «заміні» неадекватних думок реалістичними твердженнями [9].

Групова терапія та відвідування груп самодопомоги також вважаються корисними для людей 3 тривожнофобічними розладами. Групова робота допомагає мотивувати людей під час та після терапії, оскільки вона сприяє відчуттю полегшення і підтримки, усвідомленню того, що можна поділитися своїми проблемами 3 іншими, з тими, хто розуміє, що людина переживає. Усі консультативні методи лікування фобій $\epsilon$, по суті, поступовим і контрольованим способом зменшення тривожності та допомоги людям у розробці нових схем мислення та поведінки, що сприяють добробуту та життєздатності.

При тривожно-фробічному розладі використовують і гіпнотерапію. Фобії «працюють» на підсвідомому рівні. Це означає, що як би ми не переконували себе, що «щось» не загрожує життю, наш розум і тіло все одно реагують зі страхом. Метою гіпнотерапії $\epsilon$ спілкування 3 підсвідомим та зміна почуття та поведінки щодо фобії. Сам процес відбувається в дуже розслабленому, гіпнотичному стані. Якщо причина фобії $\epsilon$ незрозумілою, процес потребує певного часу, аби дістатися до чинника фобії та згадати подію, яка iï спричинила (якщо така була). Кількість потрібних сеансів різниться залежно від людини і від складності фобії. Деякі люди почуваються більш спроможними впоратися з проблемою вже після одного заняття, тоді як інші потребують постійного підкріплення. Багато гіпнотерапевтів також рекомендують методи самогіпнозу та розслаблення, що надає клієнту можливості довгостроково керувати своєю тривогою [14]. Однак, як зазначає А.Пеліссоло, отриманих даних $\epsilon$ недостатньо для підтвердження ефрективності гіпнозу при хронічних тривожних розладах будь-яких категорій, включаючи фобію або ПТСР, отже сучасна наука потребує конкретних подальших досліджень [13].

Майндфулнес при роботі 3 фобіями допомагає зменшити рівень стресу. Можливо, ця техніка не зупинить початковий приплив фоббічної тривоги, але тренування вміння «бути тут і зараз» може допомогти зменшити рівень страху і може бути використано для домашньої терапії. Для людей, які страждають від тривожно-фробічних розладів, буде корисною співпраця 3 терапевтом з метою опанування технік майндфулнес. Самостійна практика майндфулнес $\epsilon$ прекрасною самодопомогою, особливо в неприємні моменти зустрічі 3 фобічними страхами.

Медитація, глибоке дихання та прогресивна м'язова релаксація також $€$ корисними для людей з ТФР [4]. Медитативні техніки, які розроблялися століттями, практикуються в культурах усього світу з метою набуття спокою та внутрішньої гармонії. Сьогодні у нашому непередбачуваному світі медитація набуває популярності. П̈ї інкорпорування у повсякденне життя приносить чимало користі [2; 3].

Глибоке дихання - це діафрагмальне дихання, що має ряд переваг, які впливають на весь організм. Це основа майже всіх методів медитації або релаксації, які можуть зменшити рівень стресу, знизити кров'яний тиск та регулювати інші важливі процеси в організмі. Однак слід враховувати, що діафрагмальне дихання не завжди спрацьовує саме по собі - воно $\epsilon$ значно ефрективнішим у поєднанні 3 когнітивно-біхевіоральною терапією або гіпнотерапією [8].

Метод прогресивної м'язової релаксації був розроблений американським лікарем Е. Якобсоном 
у 20-х роках минулого століття. Він базувався на теорії, згідно з якою фрізична релаксація може сприяти розумовій релаксації. Якобсон виявив, що напруження і розслаблення м'язів впливає не тільки на тіло, але й на розум. Прогресивна м'язова релаксація сприяє досягненню розслаблення єдиної системи «тілорозум», що суттєво знижує рівень тривожних станів, депресії та стресу, покращує сон, зменшує відчуття фрізичного болю, нормалізує систолічний кров'яний тиск [12]. Подібний метод може позитивно вплинути на стан пацієнтів з тривожнофобічним розладом.

Висновки і перспективи. Отже, психотерапія $€$ одним 3 найплідніших підходів до лікування тривожнофоббчних розладів. Чим раніше люди звертаються по допомогу, тим краще, оскільки уникання ускладнює проблему і руйнує життя людини. Хоча лікування простих фобій часто передбачає самодопомогу, наприклад, використання техніки експозиції вдома, лікування складних фобій потребує більше часу і роботи. Вибір стратегії терапії залежать від проявів клінічної симптоматики, етапу лікування, особливостей особистості, установок і очікувань пацієнтів, актуальних ресурсів і організаційних можливостей. Існують плюси і мінуси як для психофрармакологічного, так і для психотерапевтичного лікування. Отже, найефрективніші стратегії лікування мають обиратися після глибокого багатопланового дослідження пацієнта і здійснюватися поліпрофільною командою фахівців.

\section{References}

1. Cuijpers P., Gentili C., Banos R.M., Garcia-Campayo J., Botella C., Cristea I.A. (2016). Relative effects of cognitive and behavioral therapies on generalized anxiety disorder, social anxiety disorder and panic disorder: A meta-analysis. Journal of Anxiety
Disorders, 43, 79-89. doi: 10.1016/j.janxdis.2016.09.003.

2. Danylova, T. (2014). The World without Fear and Illusions: Meditation as a Means of Overcoming Binary oppositions of Culture. International Researchers IR, 3, 2. Retrieved from

http://www.iresearcher.org/77-

$82 \% 20$ IR \%20Template \%20-

\%20Copy \%20(8).pdf.

3. Danylova, T. (2019).

Moving Beyond The "Nature - Nurture" Dichotomy: A Holistic Approach to Mental Health. Research Revolution. International Journal of Social Science \& Management, VII (6-7), 1-5.

4. Danylova. T. (2020). On Covid-19, Mental Health, and Meditation. Scientific Herald of National University of Life and Environmental Sciences of Ukraine. Series: Pedagogics, Psychology, Philosophy, 3, 11(4), 75-81.

5. Furukawa T. A., Watanabe N., Churchill R. (2007). Combined psychotherapy plus antidepressants for panic disorder with or without agoraphobia. Cochrane Database of Systematic Reviews, 1, CD004364. doi: 10.1002/14651858.CD004364.pub2.

6. Garcia, R. (2017). Neurobiology of fear and specific phobias. Learning Memory, 24(9), 462471.

7. ICD-11. International Classification of Diseases. (2020). 11 th Revision. The Global Standard for Diagnostic Health Information. World Health Organization. Retrieved from https://icd.who.int/en.

8. Jewell, T. (2018). What is Diaphragmatic Breathing? Reviewed by D.R. Wilson. Healthline. Retrieved from https://www.healthline.com/health/diaphr agmatic-breathing.

9. Joy, R. (2020). What Types of Therapy Can Help Treat a Phobia? Medically reviewed by White M.A. Healthline. Retrieved from https://www.healthline.com/health/therap y-for-phobias. 
10. Kogan, C.S., Stain D.J, Maj M., First M.B., Emmelkamp P.M.G., Reed, G.M. (2016). The classification of Anxiety and Fear-Related Disorders in the ICD-11. Depression and Anxiety, 33(12), 1141-1154. doi: 10.1002/da.22530.

11. Milosevic, I., McCabe, R.E. (Eds.). (2015). Phobias: The Psychology of Irrational Fear. Greenwood, 444 p.

12. Nunez, K. (2020). The Benefits of Progressive Muscle Relaxation and How to Do It. Reviewed by G. Minnis. Healthline. 2020. Retrieved from https://www.healthline.com/health/progre ssive-muscle-relaxation.

13. Pelissolo, A. (2016). Hypnosis for anxiety and phobic disorders: A review of clinical studies. La Presse Medicale, 45, 284-290. doi: 10.1016/j.lpm.2015.12.002.

14. Phobias. Hypnotherapy Directory. Retrieved from https://www.hypnotherapydirectory.org.uk/articles/phobias.html\#un derstandingphobias.

15. Saul, H. (2001). Phobias: Fighting the Fear. Arcade Pub, 368 p.

\title{
PSYCHOTHERAPEUTIC TREATMENT OPTIONS FOR PHOBIC ANXIETY DISORDERS: A BRIEF OVERVIEW Danylova T.V., Salata G.V., Semenov Yu.O.
}

\begin{abstract}
Nowadays, the problem of diagnosis, interpretation and selection of treatment options for phobic anxiety disorders is becoming more acute taking into account the multidimensionality of a human being. The data obtained on psychopharmacotherapy show its moderate effectiveness for phobic anxiety disorders. The combination of psychopharmacotherapy and psychotherapy, which often plays a leading role in the treatment process, works much better. The paper aims at analyzing psychotherapeutic treatment options for phobic anxiety disorders, such as exposure therapy, cognitivebehavioral therapy, group therapy and self-help groups, hypnotherapy, mindfulness, meditation, deep breathing, progressive muscle relaxation method. There are pros and cons for both psychopharmacological and psychotherapeutic treatment options. Therefore, the choice of the most effective treatment options should be determined after an in-depth examination of a patient and carried out by a multidisciplinary team of specialists.
\end{abstract}

Keywords: phobic anxiety disorders; exposure therapy; cognitive-behavioral therapy; group therapy and self-help groups; hypnotherapy; mindfulness; meditation; deep breathing; progressive muscle relaxation method. 